\title{
The Selection of Chemical Engineering Periodicals in College Libraries
}

Mr. Smith is librarian of the Aeronautical Archives of the Institute of the Aeronautical Sciences, Inc. His paper is a compression of a master's essay accepted at the School of Library Service, Columbia University, in 1942 and exemplifies one of the two series described in Miss Fay's article on pages 207-I 6 .

$\mathrm{T}$ HE PURPOSE of this essay is to consider the problem of selection of chemical engineering periodicals in the engineering college library, using as a basis the statistical method. In this method the periodical references in one or more representative source journals are counted and tabulated in order to arrive at a list of the periodicals most used by investigators in the field.

As the study was undertaken with reference to the chemical engineering curriculum, the content of this curriculum was examined as presented in the report published in 1938 by Albert B. Newman, ${ }^{1}$ chairman of the Chemical Engineering Education Committee of the American Institute of Chemical Engineers. The accrediting of chemical engineering curricula by this organization had been in operation for some time, and the data accumulated through its work in surveying individual colleges provided a basis for the section

\footnotetext{
1 Newman, A. B. "Development of Chemical Engineering Education in the United States." In American Institute of Chemical Engineers. Transactions, v. 34, Supplement, July 1938. 46p.
}

on the curriculum in Newman's report.

He points out that:

The institute does not desire to set up any hard and fast limits on the scope and character of the curriculum, nor on the relative amounts of time that should be devoted to the several groups of studies which will make up a satisfactory course of instruction in chemical engineering. The committee has, however, made a careful analysis on several occasions of the content of such courses in the more widely recognized curricula. The following distribution of time is typical of programs which produce an effective composite for the instruction of well-prepared graduates from schools offering a' four-year undergraduate course in chemical engineering. ${ }^{2}$

\section{TABLE I}

Distribution of Time in Representative Chemical Engineering Curricula

\section{Per Cent}

Chemistry ............... 25-30

Chemical Engineering ........ 20-15

Other Engineering $\ldots \ldots \ldots \ldots \ldots 12$

Mathematics .............. 12

Physics .................... 8

Mechanics ................ 6

Other Sciences ............. 2

Cultural Subjects $\ldots \ldots \ldots \ldots \ldots$. 15

Thus, as shown in Table I, the distribution of time in representative chemical engineering curricula allows chemistry 25 to 30 per cent, chemical engineering 20 to 15 per cent, and these, together with addi-

2 Newman, op. cit., p. 22-23. 
tional engineering and science courses, take up 85 per cent of the time, the remaining 15 per cent being devoted to cultural subjects. It was assumed that this distribution of time served as a reasonable partial guide in the consideration of source journals.

Two lists of periodicals were used as additional guides. One was compiled by next was Industrial and Engineering Chemistry, industrial edition, a publication of the American Chemical Society. This journal accounted for $\mathbf{2 4 . 2 2}$ per cent of the references in the Transactions of the American Institute of Chemical Engineers and was considered by specialists consulted to be the most inclusive and possibly the most important journal for

TABLE II

Sources in Which References Were Counted, Ranked According to Number of References

Tirie

Number of Number of

Industrial and Engineering Chemistry

References Self-References

Per Number of

(industrial edition) v. 28-32, 1936-40

Society of Chemical Industry. Journal

("Transactions and Communica-

tions") v. 55-59, 1936-40 .......

American Institute of Chemical Engi-

14,546

4,257

neers. Transactions, v. 32-36, 1936-

J. H. Perry. Chemical Engineers'

18.80

$7,54 \mathrm{I}$

Handbook, second ed., I94I .......

$\frac{1,253}{21,728}$

482

I 1.32

I,940

07

12.38

3,625

$\frac{3,029}{16,135}$ the Department of Chemical Engineering of the Cooper Union ${ }^{3}$ in 1936 and sent to its library for a report on holdings. The other was compiled by the American Institute of Chemical Engineers in 1939."

\section{Sources}

References were tabulated from four sources. The first was the Transactions of the American Institute of Chemical Engineers, chosen because of the importance and activity of the institute and on the advice of specialists consulted. The

${ }^{3}$ Cooper Union. Department of Chemical Engineering. [List of Periodicals.] New York City, 1936. 3 1. Typewritten.

American Institute of Chemical Engineers. Book List (No. I, Parts I \& 2) "Minimum List of Recom. mended Books for a Chemical Engineering Library." New York City, 1939. II l. Supplement, New York City, I939. 24 l. Mimeographed. chemical engineering students. The Chemical Engineers' Handbook, second edition, edited by John H. Perry, was selected as the next source when no journal in chemical engineering was found which had a sufficient number of references to serve the purpose. The Transactions of the Institution of Chemical Engineers, London, was considered, but the I940 volume was not available and therefore it was not used: The fourth source used was the "Transactions and Communications" section of the Journal of the Society of Chemical Industry, London. These four sources are listed in Table II, ranked according to the number of references found in the volumes which were used. 
"Self-references," that is, references in source journals to their own files, were included in the tabulations, as such inclusion has little effect on the final ranking of journals when each source is given equal weight by the percentage method. References to the current year were excluded in order not to give undue weight to domestic or more accessible journals. chemical engineering student is German, as will be seen from the data presented in Table III. The importance of French is somewhat less for current material than for older references. Only one French periodical achieved the final list in this study, but there were seven German journals in the final list. The number of foreign references in all the American sources

\section{TABLE III}

Number and Per Cent of English, German, and French References in the Four Sources

Title

Industrial and Engineering Chemistry

American Institute of Chemical Engineers. Transactions

J. H. Perry. Chemical Engineers' Handbook, second ed., I94I

Society of Chemical Industry. Journal (Transactions)
Language

English
German
French
All Others

English

German

French

All Others

English

German

French

All Others

English

German

French

All Others
Number of References

\begin{tabular}{rr}
10,594 & 72.83 \\
2,594 & 17.83 \\
672 & 4.63 \\
686 & 4.71 \\
\hline 14,546 & 100.00
\end{tabular}

\begin{tabular}{rr}
$I, 352$ & 80.82 \\
223 & 13.34 \\
40 & 2.39 \\
57 & 3.45 \\
\hline 1,672 & 100.00
\end{tabular}

\begin{tabular}{rr}
$\mathrm{I}, 053$ & 84.00 \\
157 & 12.95 \\
7 & .50 \\
36 & 2.55 \\
\hline 1,253 & 100.00
\end{tabular}

\begin{tabular}{rr}
2,988 & 70.19 \\
872 & 20.48 \\
226 & 5.31 \\
171 & 4.02 \\
\hline 4,257 & 100.00
\end{tabular}

That is, in the volume of Industrial and Engineering Chemistry for 1940 all references dated 1940 were excluded; in the volume for 1939, all references dated 1939 were excluded; and so on.

The most important language for the was less than 50 per cent, but in the British source was more than 50 per cent. Tables III and IV show the percentages of English, German, and French references and foreign and domestic references in each of the four sources. 


\section{TABLE IV}

Number and Per Cent of Domestic and Foreign References in American and British Sources

$\begin{array}{ccc} & \text { Domestic } & \text { Foreign } \\ \text { References } & \text { References } \\ \text { American Sources } & \text { Number PerCent } & \text { Number Per }\end{array}$

American Sources

Industrial and Engineering Chemistry.... 8,345

American Institute of Chemical Engineers.

Transactions ....................

book. Second ed., 1941 .............

British Source

Society of Chemical Industry (London)

Journal (Transactions) ............

United States government publications, especially those of the Bureau of Mines and the Journal of Research of the $\mathrm{Na}$ tional Bureau of Standards, are of great importance to the chemical engineering student. The Journal of Research and the Reports of Investigations and Bulletin of the Bureau of Mines appear in the final list of this study. The publications of state engineering experiment stations are of next importance. It should be pointed out that these publications, while they rank relatively low statistically in the
1,108

57.37

66.26

6,201

Per Cent

943

75.25

564

310

24.75

$\begin{array}{llll}I, 8 I 2 & 42.56 & 2,445 & 57.44\end{array}$

present study, are usually definitive and frequently monographic. British government publications, which have the same quality, are cited less than American ones, even in the British source. Tables $\mathrm{V}$ and VI give the number of references in the four sources to the various types of government publications and the titles of the more important ones. The titles of engineering experiment station bulletins have been included in Table VI, and state government publications and two series published by colleges are included.

\section{TABle $\mathrm{V}$}

Types of American and Foreign Government Publications Cited, Showing Number of References in American and British Sources

\begin{tabular}{|c|c|c|}
\hline American & $\begin{array}{l}\text { American } \\
\text { Sources }\end{array}$ & $\begin{array}{l}\text { British } \\
\text { Source }\end{array}$ \\
\hline Federal & 687 & 47 \\
\hline State engineering experiment stations & I 71 & 16 \\
\hline State agricultural experiment stations & 54 & 19 \\
\hline Miscellaneous state publications ....... & 24 & 3 \\
\hline British & 33 & 39 \\
\hline Other Foreign & 23 & 17 \\
\hline & 992 & 141 \\
\hline $\begin{array}{l}\text { Total References .......................... } \\
\text { Per Cent of Government Publications }\end{array}$ & $\begin{array}{rl}1 & 17,471 \\
. & 5.6\end{array}$ & $\begin{array}{r}4,257 \\
3 \cdot 3\end{array}$ \\
\hline
\end{tabular}


Titles of Principal Government and College Publications Cited, Showing Number of References in British and American Sources

Title

California. University. Publications in Engineering

Number of References

American British

Sources Source

Carnegie Institute of Technology. Mining and Metallurgical Investigations

Cornell University. Engineering Experiment Station. Bulletin

Great Britain Aeronautical Research Committee. Reports and Memoranda

Adhesives Research Committee. Reports

Department of Scientific and Industrial Research. Technical

5

5

5

5

I I

4

15

Fuel Research Board. Technical Papers

Medical Research Board. Technical Papers

Illinois. University. Engineering Experiment Station. Bulletin

Iowa State College. Engineering Experiment Station. Bulletin

Iowa State College Journal of Science

Journal of Agricultural Research (U.S. Department of Agriculture)

Journal of Research of the National Bureau of Standards

Michigan. University. Department of Engineering Research. Engineering Research Bulletin

Circular Series

Polytechnic Institute of Brooklyn. Research Note

Texas. University. Bulletin. Engineering Series

Bulletin. Science Series

U. S. Bureau of Fisheries. Investigational Report

Bureau of Labor Statistics. Bulletin

Bureau of Mines. Bulletin

Information Circular

Monographs

Reports of Investigations

Technical Papers

Department of Agriculture. Bulletin

Circular

Miscellaneous Publications

Technical Bulletin.

- Department of Agriculture. Bureau of Chemistry. Bulletin

Department of Agriculture. Bureau of Soils. Bulletin

Geological Survey. Annual Report

Bulletin

Professional Paper

National Advisory Committee for Aeronautics. Technical

Memorandum

- Technical Reports

National Bureau of Standards. Circular

Scientific Papers

Technologic Papers

Public Health Service. Public Health Bulletin

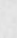


Title

Number of References $\begin{array}{cc}\text { American } & \text { British } \\ \text { Sources } & \text { Source }\end{array}$ Public Health Reports

Utah, University of, and U. S. Bureau of Mines. Technical Paper West Virginia. University. Engineering Experiment Station. Research Bulletin Technical Bulletin

34

5

5

10

24
Any journal which achieved I per cent of the references in any one source was included in the final list of journals resulting from the addition of the data from the four sources. This final list of thirtyfour journals is presented in Tables VII and VIII. Table VII shows them ranked according to the total number of references, with the data arranged by five-year periods, and Table VIII shows them ranked according to their added and average percentages of total references. Thus in Table VIII each source is given equal weight by the use of percentages.

The statistical method is not offered as a final solution to the problems of selection of periodicals in chemical engineering for the college library. In the application of the data presented, the nature of the institution which the library is serving is a major factor. A university library, for example, serving a comprehensive curriculum, may find that the majority of periodicals are applicable to the needs of two or more departments. To illustrate, the Journal of Agricultural Science, which is number thirty-three in the list of journals in Table VIII, would be a major journal in an institution giving degrees in agricultural science and would have partial value for chemistry, biology, and chemical engineering departments in the same institution. Its cost per department would be less than in an institution granting degrees in fewer subjects. In an institution giving only engineering degrees, this journal would be only partially applicable to the needs of only one department, that of chemical engineering, and thus would not be recommended for purchase.

A notable trend among libraries, that of cooperation in the purchase of expensive materials, should be considered in connection with the selection of chemical engineering periodicals. This is especially effective for valuable but less-used foreign language periodicals. Such cooperation is not recommended in respect to material which is likely to be in daily demand. For example, a complete file of Industrial and Engineering Chemistry should be in the library of an institution granting degrees in chemical engineering, as will be seen by reference to its standing in Tables VII and VIII.

\section{Quality of Periodicals}

The quality of periodicals, measured by the conclusiveness and completeness of their articles and the authority of their authors, must be considered. Two general types of periodicals appear in Tables VII and VIII, those publishing research, and trade and technical journals. Most of the former are published by scientific or engineering societies, universities, or government bodies. Of the journals listed in Tables VII and VIII, three are of the 
trade and technical type. They are Chemical and Metallurgical Engineering, Engineering and Mining Journal, and Canadian Chemistry and Process Industries. There is little doubt of the value of them to the chemical engineering student. While they publish little original research, they contain a great deal of important descriptive data on the process industries and should be available to the chemical engineering student. However, extensive purchase of journals of this type, at the expense of research material, should be avoided.

Three of the journals listed in Tables VII and VIII bear directly on chemical engineering. On the basis of the evidence in Table VII, a set of the Transactions of the American Institute of Chemical Engineers beginning in 1916 would serve most purposes in an institution giving courses in chemical engineering, as there is only one reference previous to I9I6. The same is true of Chemical and Metallurgical Engineering, which has only three references before I9I6. A complete set of the Transactions of the Institution of Chemical Engineers, London, is indicated.

In related branches of engineering, journals which are recommended as useful to chemical engineering students in all institutions are: Transactions of the American Society of Mechanical Engineers, set beginning in I9I I Transactions of the American Institute of Mining and Metallurgical Engineers, set beginning in 1916; Reports of Investigations of the U.S. Bureau of Mines, 'complete set; Mechanical Engineering, set beginning in I92 I ; Refrigerating Engineering, set beginning in $192 \mathrm{I}$; Proceedings of the American Gas Association, set beginning in I92I; Technical Publications of the American Institute of Mining and Metal- lurgical Engineers, set beginning in 1926; Engineering and Mining Journal, set beginning in 1926. These journals are listed in the order of their importance, based on the evidence in Tables VII and VIII. The sets indicated here are the ones recommended for chemical engineering students. For example, mechanical engineering students might need a set of the Transactions of the American Society of Mechanical Engineers beginning earlier than I9I I.

In industrial chemistry, continuing the recommendations based on Tables VII and VIII, Industrial and Engineering Chemistry is indispensable and a complete set from 1909 is recommended. The Journal of the Society of Chemical Industry, London, is of next importance, both the "Transactions" and "Chemistry and Industry" sections being recommended from 1900 to date. Libraries desiring completeness should have Angewandte Chemie, I900 to date, and Canadian Chemistry and Process Industries, I93I to date.

In chemistry, the Journal of the American Chemical Society, I900 to date, is recommended for all institutions giving courses in chemical engineering. Berichte der Deutschen Chemischen Gesellschaft, a complete set, and the Journal of the Chemical Society, London, are both essential, as indicated by the evidence in Tables VII and VIII. The latter has a valuable abstract section corresponding to that in the Journal of the Society of Chemical Industry. Only one index is published and it covers both sections. Libraries having only one of these will find themselves explaining throughout the year that the other section must be consulted elsewhere. Industrial and Engineering Chemistry, Analytical Edition, is recommended, 1929 
TABLe VII

Journals Cited in the Four Sources, Ranked According to Total Number of References (Data Arranged by Five-Year Periods)

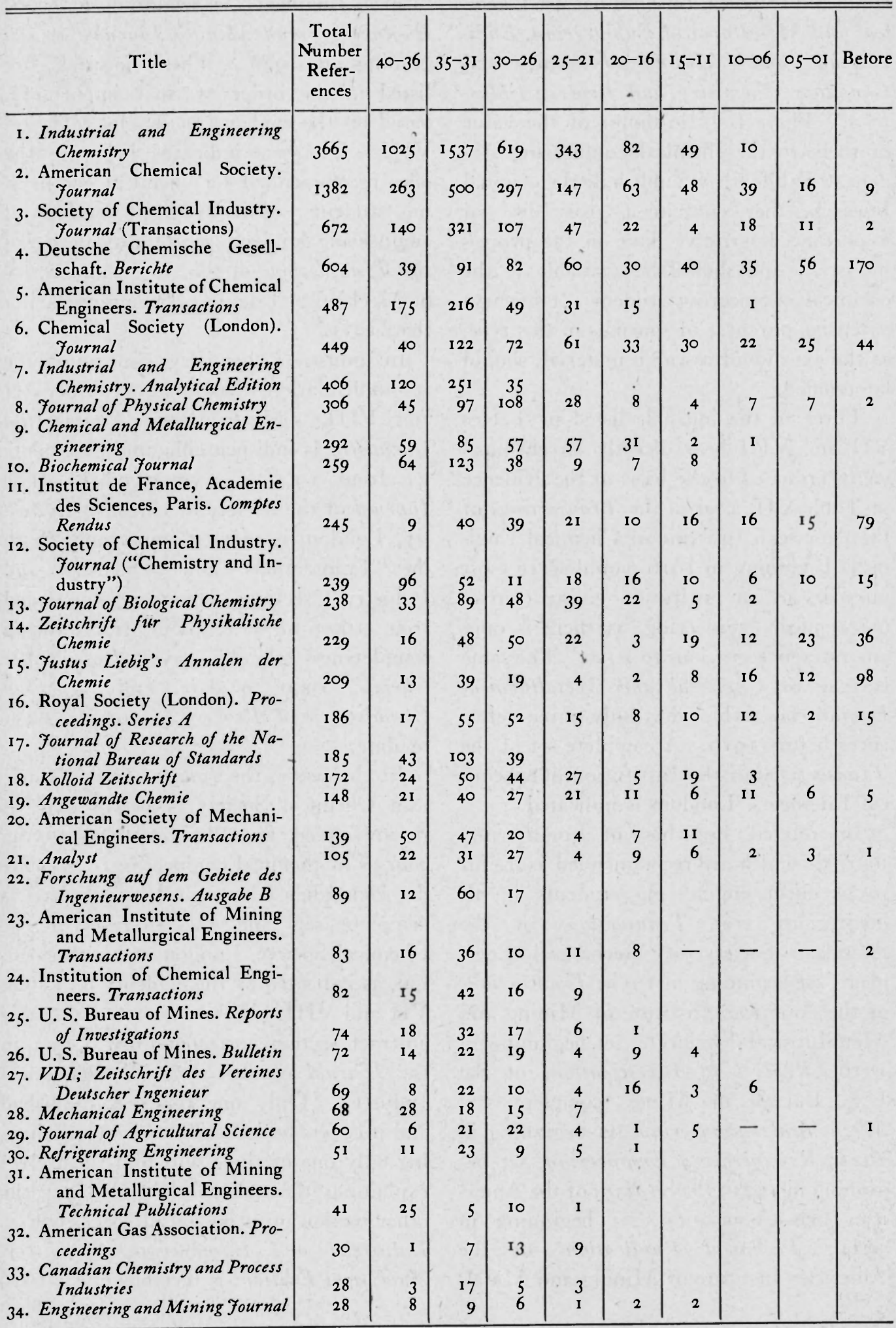




\section{TABLE VIII}

Final List of Thirty-Four Journals Cited in the Four Sources, Ranked According to Their Added and Average Percentages of Total References, with Publication Data

\section{Journal}

Added

Per Cent of

References

Average

Per Cent of

References

I. Industrial and Engineering Chemistry, v. I-32, I909-date, Washington, D.C. Monthly. \$3 per year

2. American Chemical Society. Journal, v. I-62, I879-date,

- Easton, Pa. Monthly. \$8.50 per year

3. American Institute of Chemical Engineers. Transactions, v. I-36, I 908-date, New York. Bimonthly. \$9 per year

4. Society of Chemical Industry. Journal ("Transactions and Communications"), v. I-59, I 882-date, London. Monthly. 84s. per year

5. Chemical and Metallurgical Engineering, v. I-49, 1902-date, New York. Monthly. \$3 per year

6. Deutsche Chemische Gesellschaft. Berichte, v. I-73, I866date, Berlin. Monthly. RM70 per year

7. Chemical Society. Journal, I84I-date, London. Monthly. 65s. per year

8. American Society of Mechanical Engineers. Transactions, v. I-62, I 880-date, New York. Monthly. \$12 per year

9. Industrial and Engineering Chemistry (Analytical Edition), v. I-I 2, I 929-date, Washington, D.C. Monthly. \$2.50 per year

I0. Biochemical Journal, v. I-35, I906-date, London. Monthly. 70s. per year

I I. Journal of Physical Chemistry, v. I-44, I896-date, Baltimore. Monthly. (October-June) $\$ 8$ per year

12. Royal Society of London. Proceedings. Series A. Mathematical and Physical Sciences, v. I-I76, I800-date, London. Monthly. 2 or 3 vols. per year, 30s. per vol.

13. Zeitschrift für physikalische Chemie. Abt. A: Chemische thermodynamik, kinetik, elektrochemie, eigenschaftslehre, v. I-202, I 887-date, Leipzig. Irregular. RM25-80 per vol.

14. Society of Chemical Industry. Journal ("Chemistry and Industry"), v. I-59, I 882-date, London. Weekly. Is. 9d. per no. (Included in price of complete Journal, 84s. per year)

15. Forschung auf dem gebiete des Ingenieurwesens, Ausg. B. (Includes supplement, Forschungsheft) v. I-I I, I930-date, Berlin. Bimonthly. RM25 per year

16. Journal of Biological Chemistry, v. I-136, I905-date, Baltimore. Monthly. \$4 per vol.

17. Institut de France, Academie des Sciences. Comptes Rendus Hebdomadaires des Seances . . . , v. I-210, I835-date, Paris. Weekly. $374 \mathrm{fr}$. per year

18. Justus Liebig's Annalen der Chemie, v. I-545, 1832-date, Berlin. Irregular. RMII per vol. 
Table VIII (Continued)

Final List of Thirty-Four Journals Cited in the Four Sources, Ranked According to Their Added and Average Percentages of Total References, with Publication Data

\section{Journal}

Added

Per Cent of References

19. VDI; zeitschrift des Vereines deutscher ingenieur, v. I-84, I 857-date, Berlin. Weekly. RM40 per year 2.632

Average Per Cent of References

20. Institution of Chemical Engineers. Transactions, v. I-I8, 1923-date, London. Annual

21. Journal of Research of the National Bureau of Standards, v. I-25, 1929-date, Washington, D.C. Monthly. \$3 per year

22. American Institute of Mining and Metallurgical Engineers. Transactions, v. I-I40, 1876-date, New York, 4-5 vols. per year. \$5 per vol.

23. U. S. Bureau of Mines. Reports of Investigations, No. 20003540, 1919-date, Washington, D.C. Irregular. Free

24. Mechanical Engineering, v. I-62, I906-date, New York. Monthly. \$5 per year

25. U. S. Bureau of Mines. Bulletin, No. I-435, 1910-date, Washington, D.C. Irregular, 15-75\& each

26. Refrigerating Engineering, v. I-40, 1914-date, New York. Monthly. \$4 per year

27. Angewandte Chemie, v. I-53, I887-date, Berlin. Weekly. $\mathrm{RM}_{40}$ per year

28. Kolloid-Zeitschrift, v. I-92, 1906-date, Dresden. Monthly. RM8o per year

29. Analyst (Society of Public Analysts and Other Analytical Chemists), v. 1-65, 1875-date, Cambridge, England. Monthly. 30s. per year

30. American Gas Association. Proceedings, v. 1-32, 1919-date, New York. Annual

31. American Institute of Mining and Metallurgical Engineers. Technical Publications, No. 1-1257, 1927-date, New York. Irregular

32. Engineering and Mining Journal, v. 1-141, 1866-date, New York. Monthly. \$3 per year

33. Journal of Agricultural Science, v. I-30, 1905-date, London. Quarterly. 30s. per year

34. Canadian Chemistry and Process Industries, v. 1-24, 1917date, Toronto. Monthly. \$3.50 per year

to date. The Journal of Physical Chemistry, I 900 to date; Zeitschrift für physikalische Chemie, I900 to date; and the Journal of Research of the National Bureau of Standards, complete set, are recommended for all libraries. Libraries desiring completeness should have the Bio- chemical Journal, I9I I to date; Journal of Biological Chemistry, 1916 to date; and Justus Liebig's Annalen der Chemie, a complete set. This last journal appears on the evidence to be more important for its nineteenth-century volumes than for its volumes published since I900, but the 
later volumes are consistently used and the articles in this journal are of a high order. Kolloid Zeitschrift, complete set, and Analyst, 1926 to date, are recommended for libraries desiring completeness.

\section{Foreign Language Journals}

Of the foreign language engineering journals, Forschung auf dem Gebiete des Ingenieurwesens, ausgabe $B$, on the evidence in Tables VII and VIII, is desirable in a complete set. This journal includes a valuable supplement, Forschungsheft, which contains monographic papers. VDI: Zeitschrift des Vereines deutscher ingenieur, 1900 to date, is recommended. This is a general engineering journal of a type not found in the United States.
Of the two general science journals listed in Tables VII and VIII, the Proceedings of the Royal Society, London, Series A, Mathematical and Physical Sciences, is recommended for all libraries, 1900 to date. Comptes Rendus Hebdomadaires de l'Institut de France, Academie des Sciences, because of the inconclusiveness of its articles and its high price of seventy-five dollars per year, is not recommended for the engineering college library, but it is desirable in the large university library.

The Journal of Agricultural Science, published by Cambridge University, is recommended only for the university which includes agriculture in its curriculum. 